\title{
ANALISIS PENGARUH LASER INFRAMERAH TERHADAP TINGGI DAN JUMLAH ANAKAN PRODUKTIF TANAMAN PADI
} (Oryza sativa L.)

\section{ANALYSIS OF THE EFFECT OF INFRARED LASER ON HEIGHT AND NUMBER OF PRODUCTIVE TILLERS OF PADDY (Oryza sativa L.)}

\author{
Tamara Pingki ${ }^{*}{ }^{*}$, Sudarti $^{1}$, Trapsilo Prihandono ${ }^{1}$ \\ ${ }^{1}$ Program Studi Pendidikan Fisika Fakultas Keguruan dan Ilmu Pendidikan, Universitas Jember, \\ Jl. Kalimantan Tegalboto No.37, Krajan Timur, Sumbersari, Kec. Sumbersari, Kabupaten Jember, \\ Jawa Timur 68121
}

\begin{abstract}
ABSTRAK
Laser inframerah sering diaplikasikan pada tanaman, salah satunya pada tanaman padi. Padi (Oryza sativa L.) merupakan tanaman yang hasil panennya menjanjikan untuk masyarakat Indonesia, namun tidak semua padi dapat dipanen dan tidak semuanya dapat dipasarkan. Karakteristik padi yang baik untuk dipasarkan dan dikonsumsi terdapat pada tinggi dan jumlah anakan produktif tanaman padi sesuai dengan perlakuan tertentu. Tujuan penelitian ini adalah menganalisis pengaruh laser inframerah terhadap tinggi dan jumlah anakan produktif tanaman padi. Penelitian ini dilakukan pada sawah seluas $5 \mathrm{~m}^{2}$ di Desa Ngoran, Kecamatan Nglegok, Kabupaten Blitar. Tanaman padi pada penelitian ini berjenis Inpari 13 yang berumur 48 hari setelah sebar (HSS). Karakteristik data panjang gelombang infrared memiliki rata-rata sebesar 497,53 micrometer serta pada data tinggi batang padi memiliki rata-rata sebesar $56,845 \mathrm{~cm}$. Pola hubungan antara panjang gelombang infrared dengan tinggi batang padi menunjukkan korelasi yang positif. Artinya, jika panjang gelombang infrared bertambah maka tinggi batang padi akan bertambah. Jika panjang gelombang infrared bernilai 0 maka tinggi batang padi sebesar 55,226 cm, dan jika panjang gelombang infrared naik 1 satuan maka tinggi batang padi akan naik sebesar 0,03. Pengujian asumsi residual IIDN residual data tinggi batang padi memenuhi asumsi identik, independen, dan berdistribusi normal.
\end{abstract}

Kata kunci: laser; padi; tinggi; anakan produktif

\begin{abstract}
Infrared lasers are often applied to plants, one of which is paddy. Paddy (Oryza sativa L.) is a crop with promising yields for the people of Indonesia, but not all paddy can be harvested and not all of it can be marketed. Characteristics of paddy that are good for market and consumption are found in the height and number of productive tillers of paddy plants according to certain treatments. The purpose of this research is to analyze the effect of infrared laser on the height and number of productive tillers of paddy plants. This research was conducted on $5 \mathrm{~m}^{2}$ of paddy fields in Ngoran Village, Nglegok District, Blitar Regency. The paddy plants in this study were Inpari 13, 48 days after sowing. Characteristics of infrared wavelength data has an average of 497.53 micrometers and the height data of paddy stalks has an average of $56.845 \mathrm{~cm}$. The pattern of the relationship between infrared wavelengths and paddy stem height shows a positive correlation. That is, if the infrared wavelength increases, the height of the paddy stalk will increase. If the infrared wavelength is 0 then the height of the paddy stalk is $55.226 \mathrm{~cm}$, and if the infrared wavelength is increased by 1 unit, the height of the paddy stalk will increase by 0.03. Testing the assumption of residual IIDN residual paddy stem height data fulfills the assumptions of being identical, independent, and normally distributed.
\end{abstract}

Keywords: laser; paddy; tall; productive tillers

\footnotetext{
*) Penulis Korespondensi.

E-mail : tamarapingki9981@gmail.com

Telp. $+62812-5211-8246$
} 


\section{Pendahuluan}

Gelombang elektromagnetik adalah gelombang yang tidak membutuhkan media ketika merambat. Ada beberapa jenis gelombang elektromagnetik, antara lain sinar gamma, sinar$\mathrm{X}$, ultraviolet, sinar tampak, inframerah, radar, gelombang TV maupun gelombang radio. Gelombang elektromagnetik berguna bagi kehidupan makhluk hidup. Penggunaan gelombang elektromagnetik sudah banyak dilakukan di berbagai bidang seperti dalam dunia medis maupun bioteknologi (Somianingsih, 2018).

Inframerah memiliki panjang gelombang yang lebih panjang dari cahaya tampak dan lebih pendek dari gelombang radio. Panjang gelombang inframerah di antara 0,7-1000 $\mu \mathrm{m}$ (Rianti dan Soekanto, 2020). Panjang gelombang inframerah tidak dapat terlihat oleh mata telanjang, tetapi radiasi yang ditimbulkan dapat dirasakan dan dideteksi. Inframerah dapat dibedakan menjadi tiga jenis, yaitu Near Infrared (NIR), Mid Infrared (MIR) dan Far Infrared (FIR) (Lusi et al., 2018).

Near Infrared (NIR) mempunyai keuntungan dalam menganalisis sifat biologis tanaman, antara lain analisis yang dilakukan cukup murah, waktu yang digunakan cukup singkat, tidak berbahaya bagi lingkungan, tidak membutuhkan preparasi sampel dan bersifat online. NIR pertama kali diaplikasikan pada tanaman yang berupa biji-bijian, yang kemudian digunakan pada produk makanan (Sari et al., 2016). Near Infrared (NIR) memiliki kemampuan untuk mengidentifikasi secara kualitatif dan kuantitatif pada sebuah objek padat maupun cair tanpa merusak bagianbagiannya serta pengukuran dapat dilakukan dalam jumlah besar dan waktu yang sangat singkat. Rentang panjang gelombang yang pada near infrared (NIR) ini adalah $0,75-1,5 \mu \mathrm{m}$ (Gustinasari et al., 2021). Inframerah dekat dapat digunakan sebagai teknik pengukuran dan klasifikasi kekerasan massal yang tidak merusak, otomatis, cepat, dan akurat (Maghirang \& Dowell, 2003).

Penggunaan pengamatan inframerahtampak secara teoritis lebih unggul daripada penggunaan pengamatan hanya terlihat karena kontras yang kuat antara refleksi inframerah dan terlihat vegetasi (Nijland et al., 2014). Keunggulan lain dari NIR adalah dapat mengukur kualitas internal dan eksternal suatu materi, baik pada tumbuhan, hewan maupun manusia (Samson et al., 2013). NIR juga termasuk ke dalam spektrum atau jenis inframerah yang sangat sensitif (Narsaiah et al., 2012). Suatu penelitian yang dilakukan pada benda organik menyatakan bahwa panjang gelombang near infrared (NIR) yang cocok berada pada rentang $0,5-1,2 \mu \mathrm{m}$ (Suseno \& Firdausi, 2008).

Mid Infrared (MIR) berada pada panjang gelombang dengan rentang 1,5-10 $\mu \mathrm{m}$ (Siregar \& Sinaga, 2017). Energi yang muncul akibat penggunaan MIR dapat menimbulkan vibrasi terhadap molekul. MIR dapat berguna untuk mengidentifikasi senyawa organik. Sedangkan Far Infrared (FIR) berada pada panjang gelombang dengan rentang $10-100 \mu \mathrm{m}$ (Nst \& Simbolon, 2020).

Laser FIR memiliki arti khusus dalam penerapannya pada penelitian biologi dibandingkan dengan laser lainnya. Hal tersebut dikarenakan garis spektral laser FIR tersebar di wilayah di mana mode getaran listrik longitudinal yang ditemukan di sebagian besar molekul biologis. Berdasarkan efek nontermalnya, laser FIR dapat menyebabkan variasi dalam aktivitas dan karakter makhluk hidup dengan cara yang lebih efektif. Laser FIR yang dipompa secara optik yang dikembangkan sendiri, penulis sejak tahun 1985 melakukan eksperimen dengan padi, kedelai, gandum, dan drosophila melanogaster secara kooperatif dengan beberapa lembaga yang berorientasi pada pertanian dan biologi (Yan et al., 1993).

Padi (Oryza sativa L.) sumber bahan pangan utama hampir setengah dari penduduk di seluruh dunia. Padi juga merupakan salah satu tanaman yang hasil panennya menjanjikan di Indonesia. Meskipun tanaman padi merupakan tanaman yang menjanjikan dan dibudidayakan di beberapa negara, namun dari jumlah total bibit padi yang ditanam tidak semuanya dapat dipanen dan tidak semuanya dapat dipasarkan.

Permintaan terhadap komoditas padi semakin tahun mengalami kenaikan seiring dengan melonjaknya jumlah penduduk. Segregasi tanaman padi yang nampak dengan mata adalah segregasi fenotipe, yaitu tinggi tanaman padi yang tidak seragam dan jumlah anakan produktif yang berbeda pada tiap rumpun padi.

Berdasarkan pemaparan tentang manfaat gelombang inframerah di atas, maka hal tersebut sejalan dengan usaha para petani di Indonesia terus-menerus berupaya untuk mendapatkan hasil panen yang dengan jumlah yang lebih banyak, biaya produksi lebih terjangkau, dan 
produk dengan kualitas lebih terjamin. Hasil panen tersebut dapat dioptimalkan dengan memanfaatkan keunggulan dari teknologi penginderaan optik, salah satunya dengan laser inframerah. Oleh karena itu, tujuan artikel ini adalah menganalisis beberapa panjang gelombang yang termasuk ke dalam tiga macam inframerah tersebut terhadap tinggi dan jumlah anakan produktif tanaman padi.

\section{Metode Penelitian}

\section{Lokasi Penelitian}

Penelitian ini dilakukan pada tanggal 13 September - 20 November 2021. Lokasi penelitian berada di sawah seluas $5 \mathrm{~m}^{2}$ di Desa Ngoran, Kecamatan Nglegok, Kabupaten Blitar.

\section{Alat dan Bahan}

Alat yang digunakan pada penelitian ini adalah laser inframerah dengan panjang gelombang yang berbeda-beda. Sedangkan bahan yang digunakan adalah tanaman padi jenis Inpari 13. Penyinaran dengan laser diberikan secara merata pada tanaman padi saat berumur 40 hari setelah sebar (HSS) selama 30 menit. Kemudian tinggi dan jumlah anakan produktif diukur pada saat tanaman padi berumur 68 hari setelah sebar (HSS) atau 35 hari setelah dilakukan penyinaran dengan laser.

\section{Analisis Data}

Metode analisis data yang digunakan pada penelitian ini adalah metode analisis data kuantitatif dengan analisis regresi linier sederhana.

\section{Hasil dan Pembahasan}

\section{Kartakteristik Data}

Karakteristik data adalah data diolah kemudian ditampilkan dalam bentuk visual, dari tampilan data tersebut diberi keterangan dan penjelasan sehingga mudah dipahami. Karakteristik data hasil pengamatan penelitian berupa panjang gelombang infrared dan tinggi batang padi adalah sebagai berikut.

\section{Kartakteristik Panjang Gelombang Infrared}

Karakteristik data panjang gelombang infrared menggunan Boxplot adalah sebagai berikut.

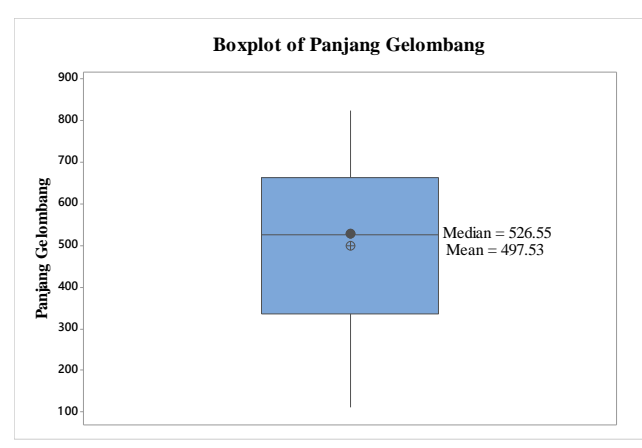

Gambar 1. Boxplot Panjang Gelombang Infrared

Berdasarkan gambar 4.1 dapat diketahui bahwa data panjang gelombang infrared memiliki rata-rata sebesar 497,53 micrometer. Dapat diketahui juga bahwa data panjang gelombang infrared tidak simetris karena garis median tidak berada tepat ditengah serta tidak terdapat data outlier.

\section{Kartakteristik Tinggi Batang Padi}

Karakteristik data tinggi batang padi menggunan Boxplot adalah sebagai berikut.

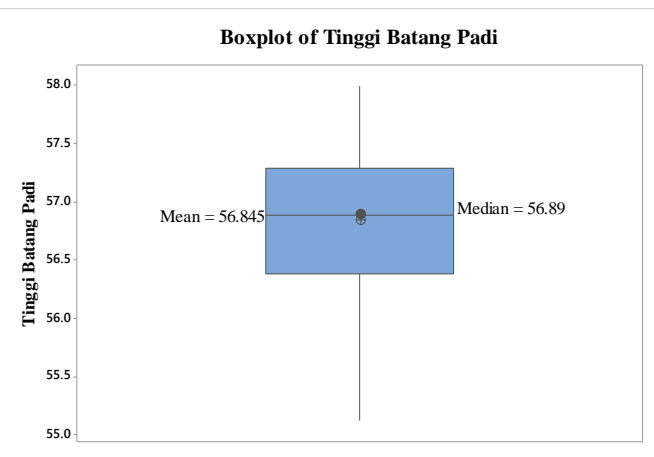

Gambar 2. Boxplot Tinggi Batang Padi

Berdasarkan gambar 4.2 dapat diketahui bahwa data tinggi batang padi memiliki rata-rata sebesar $56,845 \mathrm{~cm}$. Dapat diketahui juga bahwa data tinggi batang padi tidak simetris karena garis median tidak berada tepat ditengah serta tidak terdapat data outlier.

\section{Uji Korelasi Panjang Gelombang Infrared dan Tinggi Batang Padi}

Pola hubungan digunakan untuk mengetahui apakah data berkorelasi positif atau negatif. Berikut adalah hasil pemeriksaan korelasi panjang gelombang infrared terhadap tinggi batang padi.

Hipotesis:

$H_{0}: \rho=0 \quad$ (Tidak terdapat hubungan antara panjang gelombang infrared dan tinggi batang padi). 
$H_{1}: \rho \neq 0 \quad$ (Terdapat hubungan antara panjang gelombang infrared dan tinggi batang padi).

Taraf signifikan: $\alpha=0,05$

Daerah penolakan : $P$-value $<\alpha$

Statistik uji

$P$-value $=0,000$

Hasil statistik uji menunjukkan bahwa nilai $P$-value sebesar 0,000 lebih kecil dari $\alpha$ sebesar 0,05 sehingga dapat diputuskan bahwa tolak $\mathrm{H}_{0}$ yang artinya terdapat hubungan antara panjang gelombang infrared dan tinggi batang padi.

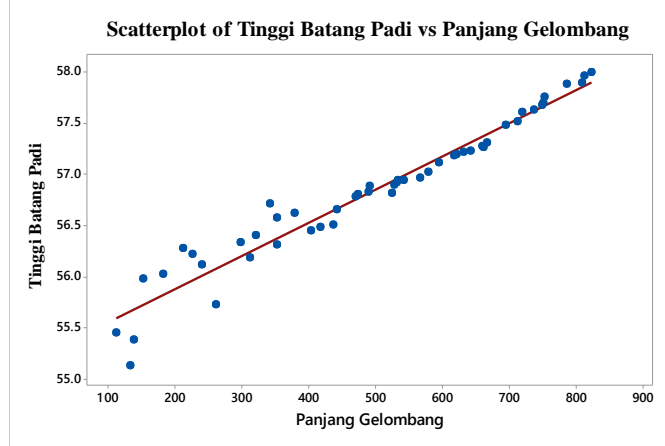

Gambar 3. Scatterplot panjang gelombang infrared vs tinggi batang padi

Gambar 3 menunjukkan bahwa pola hubungan antara korelasi panjang gelombang infrared dengan tinggi batang padi adalah berkorelasi linear positif. Grafik berbentuk garis diagonal dari arah kiri bawah ke arah kanan atas, yang berarti semakin panjang gelombang infrared maka semakin tinggi batang padi.

\section{Analisis Regresi Linear Sederhana Panjang Gelombang Infrared dan Tinggi Batang Padi}

Regresi Linear Sederhana merupakan suatu metode untuk mencari hubungan atau pengaruh dua variable atau lebih. Dalam praktikum ini variabel yang digunakan adalah panjang gelombang infrared (X) dengan tinggi batang padi (Y).

\section{Estimasi Parameter Model Regresi}

Model regresi panjang gelombang infrared dengan tinggi batang padi adalah sebagai berikut.

Tabel 1. Estimasi Model Regresi

\begin{tabular}{c}
\hline Estimasi Model \\
\hline $\begin{array}{c}\text { IPM }=55.226+0.03 \text { panjang } \\
\text { gelombang } \text { infrared }\end{array}$ \\
\hline
\end{tabular}

Tabel 1. menunjukkan bahwa jika panjang gelombang infrared bernilai 0 maka tinggi batang padi sebesar $55,226 \mathrm{~cm}$, dan jika panjang gelombang infrared naik 1 satuan maka tinggi batang padi akan naik sebesar 0,03 .

\section{Pengujian Serentak}

Pengujian serentak digunakan untuk mengetahui apakah terdapat pengaruh signifikan antara panjang gelombang infrared dengan tinggi batang padi. Uji signifikasi dapat dituliskan sebagai berikut.

Hipotesis:

$H_{0}: \hat{a}_{1}=0$ (panjang gelombang infrared tidak berpengaruh terhadap tinggi batang padi).

$H_{1}: \quad \hat{\mathrm{a}}_{1} \neq 0$ (panjang gelombang infrared berpengaruh terhadap tinggi batang padi)

Taraf Signifikan $: \alpha=0,05$

Daerah penolakan : Tolak $\mathrm{H}_{0} \mathrm{~F}_{\text {hitung }}>\mathrm{F}_{\alpha(\mathrm{v} 1, \mathrm{v} 2)}$ atau $\mathrm{P}_{\text {value }}<\alpha$

Statistik Uji :

Tabel 2. Tabel ANOVA Pengujian Serentak

\begin{tabular}{ccccccc}
\hline $\begin{array}{c}\text { S.Vari } \\
\text { asi }\end{array}$ & $\begin{array}{c}\mathrm{d} \\
\mathrm{f}\end{array}$ & SS & MS & $\mathrm{F}_{\text {hitung }}$ & $\begin{array}{c}\mathrm{F}_{\alpha(\mathrm{v} 1,}, \\
\text { v2 })\end{array}$ & $\begin{array}{c}\text { v- } \\
\text { val } \\
\text { ue }\end{array}$ \\
\hline Regre & & 21,8 & 21,8 & 837,3 & 4,04 & 0,0 \\
si & 1 & 64 & 64 & 54 & 3 & 00 \\
& 4 & 1,25 & 0,02 & & & \\
Error & 8 & 3 & 6 & & & \\
& 4 & 23,1 & & & & \\
Total & 9 & 17 & & & & \\
\hline
\end{tabular}

Tabel 2 menunjukkan bahwa nilai $\mathrm{F}_{\text {hitung }}$ sebesar 837,354 lebih besar dari $\mathrm{F}_{\alpha(\mathrm{v} 1, \mathrm{v} 2)}$ sebesar 4,043 serta nilai P-value sebesar 0,000 lebih kecil dari $\alpha$ sebesar 0,05 sehingga dapat diputuskan bahwa tolak $\mathrm{H}_{0}$ yang artinya panjang gelombang infrared berpengaruh terhadap tinggi batang padi.

\section{Pengujian Parsial}

Pengujian parsial dilakukan jika keputusan yang didapatkan dalam uji serentak adalah tolak $\mathrm{H}_{0}$. Pengujian parsial pada panjang gelombang infrared terhadap tinggi batang padi adalah sebagai berikut.

Hipotesis

$$
H_{0}: \beta_{1}=0 \quad \text { (panjang gelombang }
$$$$
\text { infrared tidak berpengaruh }
$$ 


$\begin{array}{llr} & \text { terhadap } & \text { tinggi batang } \\ & \text { padi) } & \\ H_{1}: \beta_{1} \neq 0 & \text { (panjang } & \text { gelombang } \\ & \text { infrared } & \text { berpengaruh } \\ & \text { terhadap } & \text { tinggi batang } \\ \text { padi) } & \end{array}$

Taraf signifikan $\quad: \alpha=0,05$

$\begin{array}{clcl}\text { Daerah penolakan } & : & \text { Tolak } \quad \mathrm{H}_{0} & \text { jika } \\ & \mathrm{t}_{\text {hitung }}>\mathrm{t}_{\text {tabel }(0,025,48)} & \text { atau }\end{array}$ $P$-value $<\alpha$

Stattistik uji

Tabel 3 Uji Parsial panjang gelombang infrared terhadap tinggi batang padi

\begin{tabular}{ccc}
\hline$\left|t_{\text {hitung }}\right|$ & $t_{0.025,48}$ & $P$-value \\
28,94 & 2,314 & 0,000
\end{tabular}

Tabel 4.3 menunjukkan bahwa nilai $\left|t_{\text {hitung }}\right|$ sebesar 28,94 lebih dari $t_{0.025,48}$ sebesar 2,314 serta nilai $P$-value sebesar 0,000 lebih kecil dari $\alpha$ sebesar 0,05 sehingga dapat diputuskan tolak $\mathrm{H}_{0}$ yang artinya panjang gelombang infrared berpengaruh terhadap tinggi batang padi.

\section{Kebaikan Model}

Kebaikan model pada panjang gelombang infrared terhadap tinggi batang padi adalah sebagai berikut.

Tabel 4.4 Kebaikan Model

$\frac{\overline{\text { Kebaikan Model (R-sq) }}}{94.58 \%}$

Tabel 4.4 menunjukkan bahwa panjang gelombang infrared mampu menjelaskan tinggi batang padi sebesar 94,58\% sementara 5,42\% nya dijelaskan oleh variabel lain diluar model.

\section{Uji Asumsi Residual IIDN}

Uji asumsi IIDN (Identik, Independen, Distribusi Normal) merupakan uji yang harus dilakukan untuk membuktikan apakah data yang digunakan memenuhi ketiga asumsi tersebut.

\section{Uji Identik}

Uji Identik dilakukan untuk melihat apakah residual memenuhi asumsi identik. Pengujian residual identik akan di sajikan dalam bentuk visual pada gambar 4 sebagai berikut.

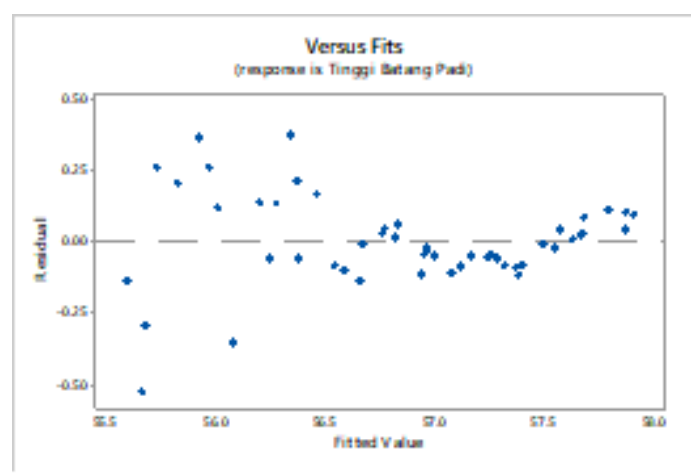

Gambar 4. Pemeriksaan asumsi identik

Gambar 4.4 menunjukkan secara visual bahwa sebaran data tidak membentuk pola tertentu sehingga dapat dikatakan sudah memnuhi asumsi identik.

\section{Uji Independen}

Uji Independen dilakukan untuk melihat apakah residual memenuhi asumsi independen. Pengujian residual independen akan di sajikan dalam bentuk visual pada gambar 5 sebagai berikut.

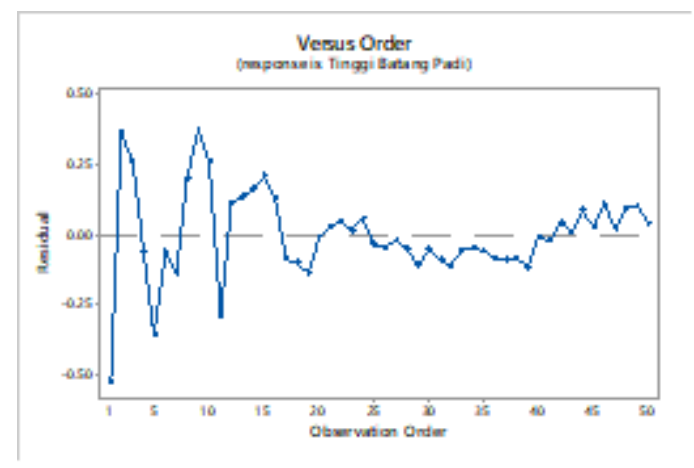

Gambar 5 Pemeriksaan asumsi independen

Gambar 5 menunjukkan secara visual bahwa sebaran data tidak membentuk pola tertentu sehingga dapat dikatakan sudah memenuhi asumsi independen.

\section{Uji Distribusi Normal}

Pengujian distribusi normal digunakan untuk mengetahui apakah residual yang didapatkan dalam regresi linear metode kuadrat terkecil mengikuti pola distribusi normal atau tidak. Pengujian residual distribusi normal akan di sajikan dalam bentuk visual pada gambar 4.6 sebagai berikut. 


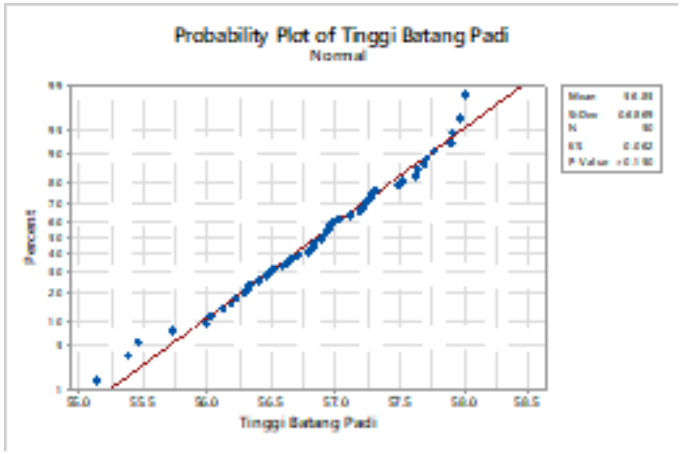

Gambar 6 Pemeriksaan distribusi normal

Gambar 6 menunjukkan secara visual bahwa sebaran data mengikuti garis linear sehingga dapat dikatakan sudah memenuhi asumsi distribusi normal.

\section{Kesimpulan}

Kesimpulan dari pengujian hubungan antara panjang gelombang infrared dengan tinggi batang padi adalah sebagai berikut.

1. Karakteristik data panjang gelombang infrared memiliki rata-rata sebesar 497,53 micrometer serta pada data tinggi batang padi memiliki rata-rata sebesar $56,845 \mathrm{~cm}$. Dapat diketahui juga bahwa data panjang gelombang infrared dan tinggi batang padi tidak simetris karena garis median tidak berada tepat ditengah serta tidak terdapat data outlier.

2. Pola hubungan antara panjang gelombang infrared dengan tinggi batang padi menunjukkan korelasi yang positif. Artinya, jika panjang gelombang infrared bertambah maka tinggi batang padi akan bertambah.

3. Jika panjang gelombang infrared bernilai 0 maka tinggi batang padi sebesar 55,226 cm, dan jika panjang gelombang infrared naik 1 satuan maka tinggi batang padi akan naik sebesar 0,03. Kebaikan model panjang gelombang infrared mampu menjelaskan tinggi batang padi sebesar $94,58 \%$ sementara $5,42 \%$ nya dijelaskan oleh variabel lain diluar model.

4. Pengujian asumsi residual IIDN residual data tinggi batang padi memenuhi asumsi identik, independen, dan berdistribusi normal.

\section{Daftar Pustaka}

Gustinasari, M., Rondonuwu, F. S., \& Muninggar, J. (2021). Pencitraan Hiperspektral Inframerah Dekat Pada Model Lapisan Acrylic Alkyd. 12.
Lusi, V. M. M., Warsito, A., \& Louk, A. C. (2018). Sistem Pengukuran Ikndeks Massa Tubuh Menggunakan Sensor Jarak Infra Merah dan Load Cell. Jurnal Fisika: Fisika Sains dan Aplikasinya, 3(1), 43-48. https://doi.org/10.35508/fisa.v3i1.593

Maghirang, E. B., \& Dowell, F. E. (2003). Hardness Measurement of Bulk Wheat by Single-Kernel Visible and Near-Infrared Reflectance Spectroscopy. Cereal Chemistry Journal, 80(3), 316-322. https://doi.org/10.1094/CCHEM.2003.80. 3.316

Narsaiah, K., Jha, S. N., Bhardwaj, R., Sharma, R., \& Kumar, R. (2012). Optical Biosensors for Food Quality and Safety Assurance-A Review. Journal of Food Science and Technology, 49(4), 383-406. https://doi.org/10.1007/s13197-011-04376

Nijland, W., de Jong, R., de Jong, S. M., Wulder, M. A., Bater, C. W., \& Coops, N. C. (2014). Monitoring Plant Condition and Phenology Using Infrared Sensitive Consumer Grade Digital Cameras. Agricultural and Forest Meteorology, 184, 98-106. https://doi.org/10.1016/j.agrformet.2013.0 9.007

Nst, Z., \& Simbolon, R. (2020). Penerapan Serta Validasi Metode Spektrofotometri Inframerah Pada Penetapan Kadar Ibuprofen Dalam Sediaan Tablet. 3, 9.

Samson, E., Semangun, H., \& Rondonuwu, F. S. (2013). Analysis of Carotenoid Content of Crude Extract of Tongkat Langit Banana Fruit (Musa Troglodytarum) Using NIR Spectroscopy (Near Infrared). 5.

Sari, H. P., Purwanto, Y. A., \& Budiastra, I. W. (2016). Pendugaan Kandungan Kimia Mangga Gedong Gincu Menggunakan Spektroskopi Inframerah Dekat (Prediction of Chemical Contents in 'Gedong Gincu' Mango using Near Infrared Spectroscopy). Jurnal Agritech, 36(03), 294. https://doi.org/10.22146/agritech.16599

Siregar, A. M., \& Sinaga, H. J. (2017). Studi Penentuan Semikonduktor Melalui Kajian Celah Energi Kompleks Senyawa BePorfirin Menggunakan Metode Komputasi Semiempiris ZINDO/1. EINSTEIN $e$ - 
Jurnal Ggratech 11 (2) 43-49, Desember 2021

JOURNAL,

https://doi.org/10.24114/einstein.v5i1.722 5

Somianingsih, M. G. (2018). Pengaruh Penyinaran Terhadap Pertumbuhan Kacang Hijau. Faktor Exacta, 11(3). https://doi.org/10.30998/faktorexacta.v11i 3.2788

Suseno, J. E., \& Firdausi, K. S. (2008). Rancang Bangun Spektroskopi FTIR (Fourier
e-ISSN : 2621-7236

p-ISSN : 1858-134X

Transform Infrared) Untuk Penentuan Kualitas Susu Sapi. 11, 6.

Yan, S., Xiong, S., \& Su, J. (1993). Far-Infrared Irradiation Experiments with Paddy Rice, Soybeans, Wheat, and Drosophila Melanogasters (J. A. DeShazer \& G. E. Meyer, Eds.; pp. 304-306). https://doi.org/10.1117/12.144041 